\title{
BULK CHEMISTRY OF KARST SEDIMENT DEPOSITS
}

\section{Mohammad Shokri}

West Virginia University, Dept. of Geology and Geography, 98 Beechurst Ave., Morgantown, WV, 26506, USA, moshokri@mix.wvu.edu

Dorothy J. Vesper

West Virginia University, Dept. of Geology and Geography, 98 Beechurst Ave., Morgantown, WV, 26506, USA, djvesper@mail.wvu.edu

\section{Ellen K. Herman}

Bucknell University, Dept. of Geology and Environmental Geosciences, 1 Dent Drive, Lewisburg, PA, 17837, USA, ekh008@bucknell.edu

\section{Ljiljana Rajic}

Northeastern University, Dept. of Civil and Environmental Engineering, 360 Huntington Ave., Boston, MA, 02115, USA,l.rajic@neu.edu

\section{Kimberly L. Hetrick}

Northeastern University, Dept. of Civil and Environmental Engineering, 360 Huntington Ave., Boston, MA, 02115, USA, hetrick.k@husky.neu.edu

\section{Ingrid Y. Padilla}

University of Puerto Rico, Mayagüez, Dept. of Civil Engineering and Surveying, Calle Yagrumo, Mayagüez, PR, 00681, USA, ingrid.padilla@upr.edu

\section{Akram N. Alshawabkeh}

Northeastern University, Dept. of Civil and Environmental Engineering, 360 Huntington Ave., Boston, MA, 02115, USA,aalsha@neu.edu

\section{Abstract}

Sediments are ubiquitous in karst systems and play a critical role in the fate and transport of contaminants. Sorbed contaminants may be stored on immobile sediments or rapidly dispersed on mobile sediments. Sediments may also influence remediation by either enhancing or interfering with the process. To better understand the potential effects of sediments on remediation, we conducted physical and chemical characterizations of 11 sediment samples from 7 cave and spring deposits from karst regions of Tennessee, Virginia, and West Virginia. The samples were analyzed for particle-size distribution using sieves and laser diffraction particle analysis. The sediment size fraction $<2 \mathrm{~mm}$ (sand, silt, and clay) was analyzed for slurry $\mathrm{pH}$ and specific conductivity (SC) using electrodes and for bulk total carbon, organic carbon, nitrogen and sulfur on an ElementarTM Vario MAX Cube CNS. The same $<2 \mathrm{~mm}$ fraction was subjected to a pseudo-total extraction using aqua regia with subsequent solution analysis by inductively coupled plasma-optical emission spectrometry (ICP-OES).

Most of the samples were dominated by the $<2 \mathrm{~mm}$ size fraction. Their slurry pHs ranged from 6.8 to 8.4 and their SCs ranged from 45 to $206 \mu \mathrm{S} / \mathrm{cm}$ with the exception of two high SC samples (726 and $8500 \mu \mathrm{S} / \mathrm{cm}$ ). The fraction of organic carbon $\left(\mathrm{F}_{\mathrm{oc}}\right.$ ) in the sediments ranged from $<0.1$ to $2 \%$. The sample from a saltpeter cave historically used for gunpowder production contained the highest concentrations of $\mathrm{N}$ and $\mathrm{S}(\sim 3 \mathrm{~g} / \mathrm{kg})$ but lower total $\mathrm{C}$ than some of the spring samples. The pseudo-total extractions were analyzed for $\mathrm{Al}, \mathrm{Ca}, \mathrm{Fe}, \mathrm{Mg}$, and $\mathrm{Mn}$. Of those elements, $\mathrm{Mg}$ was the most consistent across the locations $(2.0-6.1 \mathrm{~g} / \mathrm{kg})$, and $\mathrm{Ca}$ was the most variable $(1.4-52 \mathrm{~g} / \mathrm{kg})$. Given the importance of particle size and elemental concentrations in chemical reactions and remediation, more data of this type are needed to predict contaminant fate and transport and to plan successful remediation projects. 


\section{Introduction}

Sediments are ubiquitous in karst systems and play a critical role in the fate and transport of contaminants. Contaminants readily sorb to sediments in all aquatic settings; if the sediments are mobile, contaminant transport can be facilitated but if the sediments are immobile then transport can be slowed causing longterm storage of contaminants. The potential for either outcome is accentuated in a karst aquifer because of (1) the ease with which sediments can be introduced to the aquifer; (2) the large mass of sediments that may be present; and (3) an open matrix that permits solid transport. Furthermore, the groundwater velocity in karst aquifers may respond rapidly and dramatically to storm events altering the distribution between mobile and deposited sediments. Numerous recent studies have reported punctuated transport of sediments during storms (Dogwiler and Wicks, 2004; Herman et al., 2008; Mahler and Lynch, 1999; Reed et al., 2010) and contaminant transport in association with sediments (Loop and White, 2001; Talarovich and Krothe, 1998; Vesper and White, 2003).

Sediments may also pose challenges for the remediation of karst aquifers. Remedial techniques that employ oxidation-reduction processes, such as bioremediation or electrochemical remediation, may be particularly prone to complications from sediments. Sediments can interfere with both redox and $\mathrm{pH}$ buffering capacity of the groundwater; sediments rich in redox-active species such as $\mathrm{Fe}$ and Mn can either enhance or interfere with the remedial process and well-buffered water samples can interfere with technologies relying on $\mathrm{pH}$ changes (e.g., Fenton reaction). For example, a remediation approach that relies on the addition of energy to change the redox state of the system may be forced to first change the states of elements in the sediments before it influences the contaminants of interest. The significance of this problem depends on the elemental concentrations and the associated standard reduction potentials.

The purpose of this study was to characterize karst sediments with a range of chemistries so that they could be used for remediation experiments. The purpose was not to characterize representative samples or to place them into the geologic context of each location. This paper reports the preliminary data obtained.

\section{Methods}

Sediments were collected from seven springs and caves in Tennessee, Virginia, and West Virginia (Table 1). The samples were collected from a small springhouse (believed to be largely mobile sediments) and deposits along cave streams that appear to have been in place for the long term. Several samples were obtained from Worley Cave, a location known to contain abundant Mn-oxidizing bacteria (Carmichael et al., 2013). One sediment sample was collected from a thermal, ironrich, tufa-precipitating spring (CHAL) and one from a saltpeter cave (POLF) to provide a broader range of sediment chemical types. All samples were collected from locations believed to be free of contamination so that the results represent natural background conditions.

The sediments were collected as grab samples and composited manually. After air-drying, aliquots were created using a splitter. Particle sizes were determined on triplicates by sieving with subsequent analysis of the silt and clay fraction using a Beckman Coulter LS 13320 single-wavelength laser diffraction particle analyzer. A separate aliquot of each sample was passed through a 2-mm sieve and retained for the chemical analyses.

Specific conductance (SC) and $\mathrm{pH}$ were measured using calibrated Hanna Instruments laboratory electrodes on slurries shaken at $100 \mathrm{rpm}$ for 1 hour Following

\begin{tabular}{|c|c|c|}
\hline Location & $\begin{array}{c}\text { Sample } \\
\text { IDs }\end{array}$ & Description \\
\hline $\begin{array}{c}\text { Crabtree } \\
\text { Farm } \\
\text { Spring, WV }\end{array}$ & $\begin{array}{c}\text { CRAB1 } \\
\text { CRAB2 }\end{array}$ & $\begin{array}{c}\text { Sediment from a small springhouse; } \\
\text { samples taken on different dates. }\end{array}$ \\
\hline $\begin{array}{c}\text { Dropping } \\
\text { Lick Cave, } \\
\text { WV }\end{array}$ & DLBK & $\begin{array}{c}\text { From a high bank of deposited } \\
\text { sediments along a cave stream. }\end{array}$ \\
\hline $\begin{array}{c}\text { Miss Effie } \\
\text { Cave, WV }\end{array}$ & MEFF, & $\begin{array}{c}\text { From a deposit on the outside of a } \\
\text { stream meander bend; MEFFC is a } \\
\text { sample from a darker crust on the } \\
\text { surface of the deposit. }\end{array}$ \\
\hline $\begin{array}{c}\text { Rocky } \\
\text { Parsons } \\
\text { Cave, WV }\end{array}$ & RPMS & $\begin{array}{c}\text { Sediment from the main passage in a } \\
\text { recently discovered cave that was dug } \\
\text { open by the landowner. }\end{array}$ \\
\hline $\begin{array}{c}\text { Worley } \\
\text { Cave, TN }\end{array}$ & $\begin{array}{c}\text { WORL1, } \\
\text { WORL2, }\end{array}$ & $\begin{array}{c}\text { Composite samples from a cave } \\
\text { known to contain Mn-metabolizing } \\
\text { microbes (Carmichael et al., 2013). }\end{array}$ \\
\hline $\begin{array}{c}\text { Sweet } \\
\text { Chalybeate } \\
\text { Spring, VA }\end{array}$ & $\begin{array}{c}\text { CHAL } \\
\text { (tufa) }\end{array}$ & $\begin{array}{c}\text { From the spring run of a thermal } \\
\text { spring actively depositing tufa. }\end{array}$ \\
\hline $\begin{array}{c}\text { Anonymous } \\
\text { Cave, VA }\end{array}$ & $\begin{array}{c}\text { POLF } \\
\text { (saltpeter) }\end{array}$ & $\begin{array}{c}\text { From the floor of historic saltpeter } \\
\text { excavations. }\end{array}$ \\
\hline
\end{tabular}

Table 1. Sample descriptions. 
published methods (Hanlon, 2015; Kalra, 1995), a 1:1 sediment-to-water ratio was used for $\mathrm{pH}$ and a 1:2 ratio for SC; replicates of 6 were measured.

The $<2$ mm sediment was analyzed on an ElementarTM Vario MAX Cube CNS for total carbon, nitrogen, and sulfur. Organic carbon was determined on the same instrument but after first pre-treating the sediment with concentrated hydrochloric acid to dissolve any inorganic carbon. Sample CHAL, from the tufa-depositing spring, completely dissolved during the pre-treatment process.

Pseudo-total extractions were completed in replicates of three. Approximately 3 grams of each sediment sample $(<2 \mathrm{~mm})$ was subjected to an aqua regia solution for 16 hours at room temperature followed by heating for 2 hours at $130^{\circ} \mathrm{C}$ in a CEM MARS Express microwave. The extractant solution was filtered and analyzed using inductively coupled plasma-optical emission spectrometry (Agilent 720 ICP-OES). All concentrations are reported relative to the initial dry mass.

\section{Results and Discussion}

Sediment particle sizes ranged from sand to clay (Figure 1). Three of the sediments were dominated by sands (DLBK, MEFF, and MEFFC): these samples were collected from bank deposits on the sides of active cave streams. Sample DLBK was taken approximately 1 meter above the cave floor from a $>2$-meter high sediment deposit. The bank deposits in MEFF are thinner ( $<1$ meter); the MEFF sample was a composite from the top $10 \mathrm{~cm}$ of sediment and MEFFC was from a darkened crust on top of the sediment. The spring samples (CRAB1, CRAB2, and CHAL) were fine-grained with some gravel. The two CRAB samples were collected from a springhouse that periodically fills with solids; this material is presumed to originate from the mobile sediments transported by the spring water. Sample CHAL was obtained from a tufa-depositing spring. Based on sample dissolution during the addition of acid, this sediment contained nearly all carbonate precipitates.

The average slurry pHs (Figure 2) were lowest for the spring samples from CRAB (6.7 to 6.8) and highest for the cave samples from WORL (8.2 to 8.4). The samples collected from limestone caves generally had pHs greater than 7.7; the samples from springs (CRAB1, CRAB2, and CHAL) and from the saltpeter cave (POLF) had slightly lower $\mathrm{pH}$ values (Figure 2). The range of $\mathrm{pH}$ values measured is comparable to that reported for

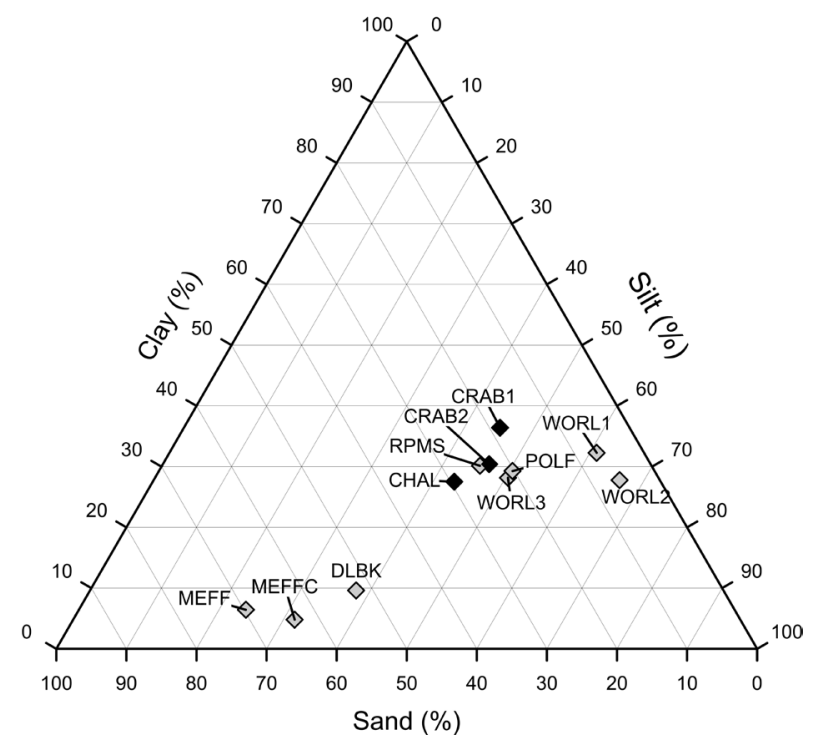

Figure 1. Relative distribution of sand, silt, and clay fractions. Sediments from springs (black) and cave deposits (light gray). Averages from three replicate samples are shown.

sediments from a Chinese cave system where $\mathrm{pH}$ ranged from 7.8 to 8.2 (Yun et al., 2016).

Most of the measured SCs ranged between 44 and $210 \mu \mathrm{S} / \mathrm{cm}$ (Figure 2). The tufa spring sample CHAL was higher $(726 \mu \mathrm{S} / \mathrm{cm})$ and the saltpeter sample POLF was significantly higher $(8500 \mu \mathrm{S} / \mathrm{cm})$ than the others.

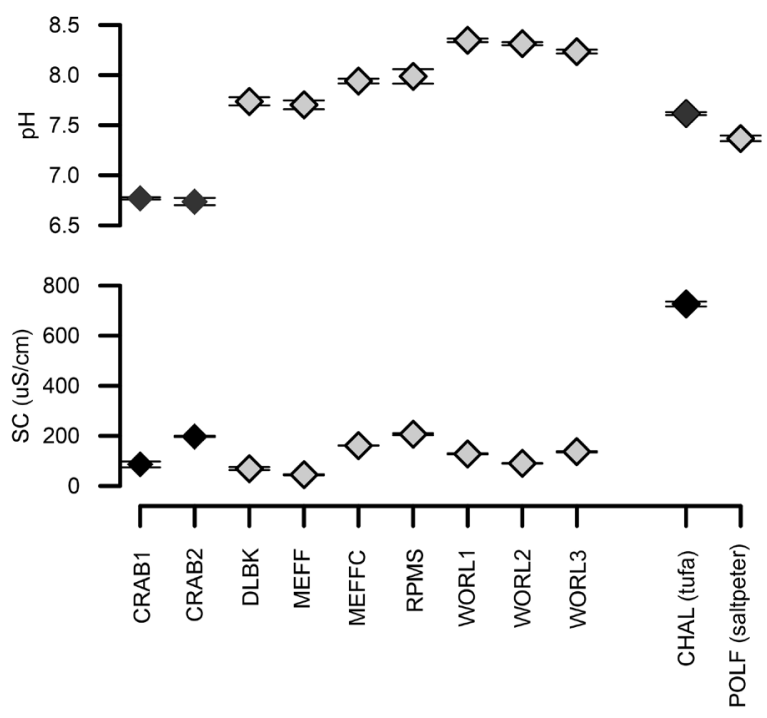

Figure 2. $\mathrm{pH}$ and SC from slurry samples from springs (black) and cave sediments (gray). Error bars are standard deviations for replicates of 6 . The SC for POLF is not shown $(8,500+/-158 \mu \mathrm{S} / \mathrm{cm})$. 
The bulk concentrations of $\mathrm{C}, \mathrm{N}$, and $\mathrm{S}$ varied by location (Table 2). Total $\mathrm{C}$ concentrations are a mixture of inorganic and organic carbon. CHAL, the sample from the tufa-depositing spring, contained the highest concentration of total $\mathrm{C}$ but contained no organic carbon (and thus has effectively $0 \% \mathrm{~F}_{\mathrm{oc}}$ ). The other spring samples (CRAB1 and CRAB2) contained the next highest concentrations of carbon.

Organic carbon plays a critical role in the transport and storage of organic contaminants because sorption is generally proportional to the concentration of organic carbon naturally present in the sediments (Schwarzenbach et al., 2002). Spring sediments CRAB1 and CRAB2 contained the highest concentrations of organic carbon followed by the MEFFC crust sample. The range of Foc in this study $(0.1-1.9 \%)$ is comparable to reported data from karst sites in KY (0.15-2.0\%) by Vesper and White (2004) and sites in China (0.2 to $0.7 \%$ ) by Yun et al. (2016). Sediments with high concentrations of organic carbon are expected to affect redox-based remedial actions.

The POLF saltpeter sample contained the highest concentrations of $\mathrm{N}$ and $\mathrm{S}$ as would be expected. Saltpeter caves were historically used for gunpowder production (Hill et al., 1981; Powers, 1981). Although these are unusual deposits, the elevated concentrations

\begin{tabular}{|l|c|c|c|c|}
\hline Sample & $\begin{array}{c}\text { Total C } \\
(\mathrm{g} / \mathrm{kg})\end{array}$ & $\mathrm{F}_{\text {oc }}(\%)$ & $\mathrm{N}(\mathrm{g} / \mathrm{kg})$ & $\begin{array}{c}\mathrm{S}(\mathrm{g} / \\
\mathrm{kg})\end{array}$ \\
\hline CRAB1 & 15.6 & $\sim 1.6$ & 1.51 & 0.33 \\
\hline CRAB2 & 23.9 & 1.81 & 2.00 & 0.47 \\
\hline DLBK & 9.99 & 0.56 & 0.55 & 0.70 \\
\hline MEFF & 6.52 & 0.42 & 0.44 & 0.61 \\
\hline MEFFC & 13.0 & 1.02 & 1.01 & 0.45 \\
\hline RPMS & 4.29 & 0.32 & 0.72 & 0.30 \\
\hline WORL1 & 1.21 & 0.10 & 0.35 & 0.44 \\
\hline WORL2 & 1.10 & 0.09 & 0.32 & 0.23 \\
\hline WORL3 & 8.20 & 0.26 & 0.59 & 0.27 \\
\hline CHAL (tufa) & 33.9 & $\sim 0$ & 1.23 & 0.41 \\
\hline POLF (saltpeter) & 10.0 & 0.53 & 3.17 & 2.84 \\
\hline
\end{tabular}

Note: Organic-C concentration at CRAB1 was slightly higher than the total $\mathrm{C}$ indicating the values agreed within resolution of the measurement; Organic-C could not be measured for CHAL because the sample dissolved when acid was added. $\mathrm{F}_{o c}$ is the fraction of organic carbon (the concentration reported as a percent). The fraction of organic carbon $\left(\mathrm{F}_{\mathrm{oc}}\right)$ is the measured concentration $(\mathrm{mg} / \mathrm{kg}$ of dry mass) expressed as percent.

Table 2. Bulk chemistry for carbon, nitrogen, and sulfur. of redox-sensitive species indicate that sediments of this type would be expected to have a major impact on remediation processes. All other samples had $<2 \mathrm{~g} / \mathrm{kg} \mathrm{N}$ and $<1 \mathrm{~g} / \mathrm{kg} \mathrm{S}$.

Solutions from the pseudo-total extractions were analyzed for $\mathrm{Al}, \mathrm{Ca}, \mathrm{Fe}, \mathrm{Mg}$, and $\mathrm{Mn}$ (Table 3). The $\mathrm{Ca}$ and $\mathrm{Mg}$ were included as proxies for carbonate minerals, the $\mathrm{Al}$ for clays, and the $\mathrm{Fe}$ and $\mathrm{Mn}$ as redox-sensitive species that may affect the remedial processes.

The relative concentrations of the extracted element groups (Figure 3) are comparable to a similar data set collected from Kentucky (Vesper, 2002). The 2002 Kentucky dataset includes three aquifer samples collected during drilling operations and six spring sediment samples. Nearly all of the samples contain more $\mathrm{Al}$ than $\mathrm{Fe}, \mathrm{Mn}, \mathrm{Ca}$, or $\mathrm{Mg}$. Of those elements, $\mathrm{Mg}$ concentrations were the most consistent across the locations $(2.0-6.1 \mathrm{~g} / \mathrm{kg})$, and $\mathrm{Ca}$ was the most variable $(1.4-52 \mathrm{~g} / \mathrm{kg})$.

$\mathrm{Al}$ concentrations in karst sediments have been closely associated with metals. In Vesper and White (2003) the $\mathrm{Al}$ in suspended sediments correlated closely with concentrations of $\mathrm{Fe}, \mathrm{As}, \mathrm{Cr}, \mathrm{Pb}$, and Ni. Similarly, correlations between $\mathrm{Al}$ and $\mathrm{Ni}, \mathrm{Cr}, \mathrm{Cu}$, and $\mathrm{Cd}$ have been reported for sediments deposited at the karst sediments at the Plitvice Lakes National Park in Croatia (Mikac et al., 2011). In this study, the $\mathrm{Al}$ concentration does not correlate closely with either Fe or Mn (Figure 4).

\begin{tabular}{|l|c|c|c|c|c|}
\hline Location & $\begin{array}{c}\mathrm{Ca}(\mathrm{g} / \\
\mathrm{kg})\end{array}$ & $\begin{array}{c}\mathrm{Mg}(\mathrm{g} / \\
\mathrm{kg})\end{array}$ & $\begin{array}{c}\mathrm{Al}(\mathrm{g} / \\
\mathrm{kg})\end{array}$ & $\begin{array}{c}\mathrm{Fe}(\mathrm{g} / \\
\mathrm{kg})\end{array}$ & $\begin{array}{c}\mathrm{Mn}(\mathrm{g} / \\
\mathrm{kg})\end{array}$ \\
\hline CRAB1 & 2.50 & 4.37 & 34.2 & 20.7 & 0.41 \\
\hline CARB2 & 2.95 & 5.21 & 36.9 & 20.0 & 0.21 \\
\hline DLBK & 7.55 & 5.02 & 10.1 & 16.5 & 0.68 \\
\hline MEFF & 3.78 & 3.96 & 19.3 & 15.8 & 0.45 \\
\hline MEFFC & 4.10 & 3.84 & 13.2 & 18.4 & 0.69 \\
\hline RPMS & 4.97 & 5.06 & 60.6 & 48.1 & 2.06 \\
\hline WORL1 & 1.82 & 4.66 & 18.0 & 25.2 & 0.44 \\
\hline WORL2 & 1.43 & 4.51 & 20.7 & 25.3 & 0.46 \\
\hline WORL3 & 15.2 & 6.10 & 24.5 & 24.7 & 0.46 \\
\hline CHAL (tufa) & 51.6 & 3.09 & 16.7 & 102 & 0.50 \\
\hline POLF (saltpeter) & 16.3 & 6.09 & 23.6 & 25.1 & 0.80 \\
\hline
\end{tabular}

Table 3. Average concentrations of elements from pseudo-total extractions. 


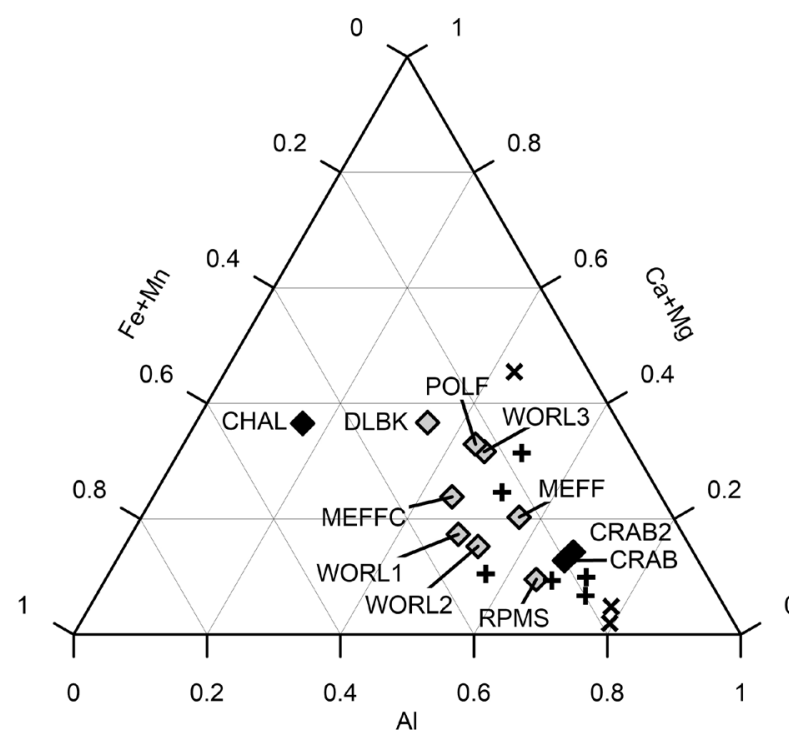

Figure 3. Pseudo-total chemistry data expressed as molar fractions of the included elements. Data from this study from springs (black diamonds) and cave sediments (gray diamonds). Samples from Kentucky-Tennessee from springs (+) and conduit sediment samples (X) from Vesper (2002).

The $\mathrm{Ca}$ and $\mathrm{Fe}$ concentrations were highest in the iron-rich tufa-depositing spring. This is a thermalmineral spring and can be expected to have a different sediment chemistry than do the other locations. It has been provided in this study as an example of the range of possible sediments that may be encountered in karst areas.

The second highest Fe concentration was measured in RPMS along with the highest Mn concentration. This sample was collected from a cave located in a karst window; this cave was recently discovered by the landowner during building excavation. No water was flowing over the sediment at the time of sample collection although there were indications of previous water flow.

\section{Summary}

The concentration data obtained for sediments in this study are provided as an example of the potential materials encountered in sediments that may influence remediation activities. Most of the recent research conducted on karst sediments is focused on sediment size and transport processes rather on the sediment chemistry. The lack of significant correlations for $\mathrm{Al}$

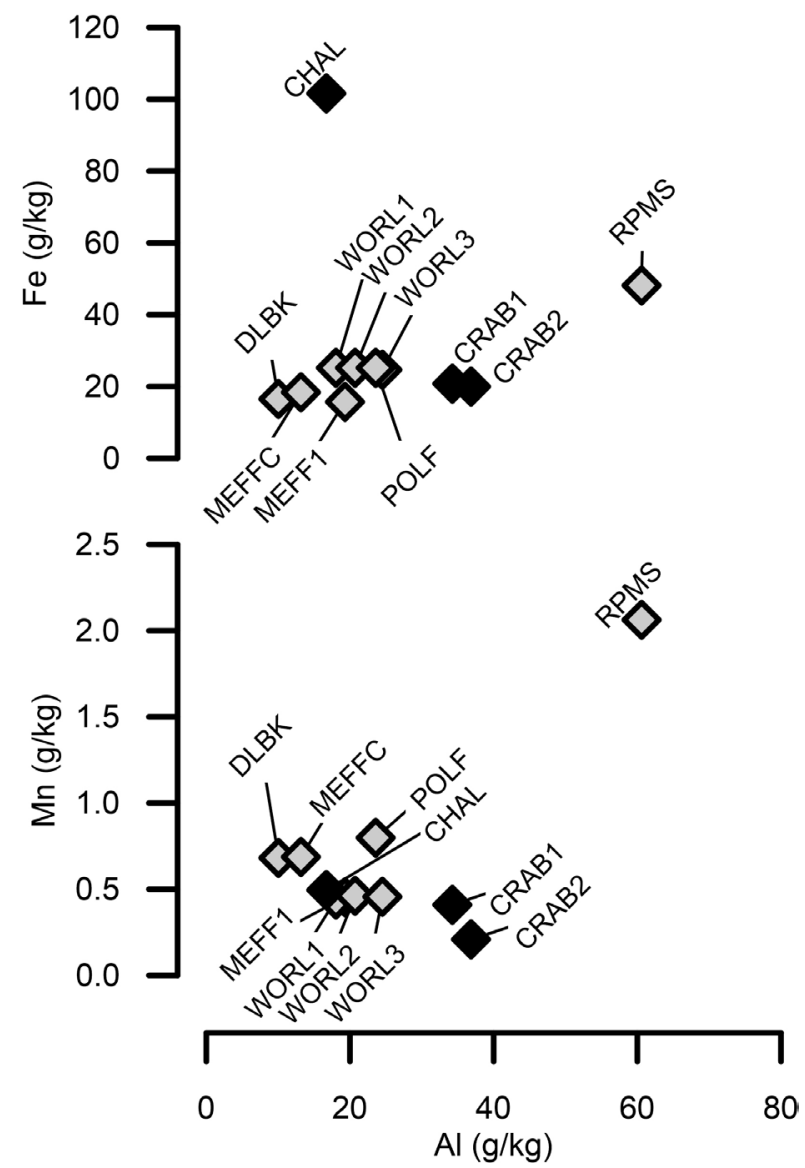

Figure 4. Comparison of $\mathrm{Fe}$ and $\mathrm{Mn}$ concentrations with Al for sediment samples from springs (black diamonds) and caves (gray diamonds).

with particle size, Fe or Mn may be due to the small number of samples. The sediments included in this study provide an example of different chemistries that exist in karst systems. More information of this type is needed for the design and evaluation of remedial systems.

\section{Acknowledgements}

This work was supported by Award Number P42ES017198 from the National Institute of Environmental Health Sciences. The content is solely the responsibility of the authors and does not necessarily represent the official views of the National Institute of Environmental Health Sciences or the National Institutes of Health.

The authors would like to thank the landowners who allowed us to collect sediments and the people who assisted in sediment collection: Dr. Suzanne Brauer, Emily Bausher, Crabtree Family, Bill Jones, Kyle Lee, Rocky Parsons, Myron Pierson, and members of the 
Indian Creek Watershed Association. We would also like to thank Dr. Louis McDonald for the CNS analyses.

\section{References}

Carmichael MJ, Carmichael SK, Santelli CM, Strom A, Bräuer SL. 2013. Mn(II)-oxidizing Bacteria are Abundant and Environmentally Relevant Members of Ferromanganese Deposits in Caves of the Upper Tennessee River Basin. Geomicrobiology Journal 30 (9): 779-800.

Dogwiler T, Wicks CM. 2004. Sediment entrainment and transport in fluviokarst systems. Journal of Hydrology 295 (1): 163-172.

Hanlon EA. 2015. Soil pH and Electrical Conductivity: A County Extension Soil Laboratory Manual. U Florida Institute of Food and Agricultural Sciences, Publication \#CIR1081.

Herman EK, Toran L, White WB. 2008. Threshold events in spring discharge: Evidence from sediment and continuous water level measurement. Journal of Hydrology 351 (1): 98-106.

Hill CA, DePaepe D, Eller PG, Hauer PM, Powers J, Smith MO. 1981. Saltpeter Caves of the United States. NSS Bulletin 43 (4): 84-87.

Kalra Y. 1995. Determination of $\mathrm{pH}$ of soils by different methods: collaborative study. Journal of AOAC International 78 (2): 310-324.

Loop CM, White WB. 2001. A conceptual model for DNAPL transport in karst ground water basins. Ground Water 39 (1): 119-127.

Mahler BJ, Lynch FL. 1999. Muddy waters: temporal variation in sediment discharging from a karst spring. Journal of Hydrology 214: 165-178.

Mikac I, Fiket Ž, Terzić S, Barešić J, Mikac N, Ahel M. 2011. Chemical indicators of anthropogenic impacts in sediments of the pristine karst lakes. Chemosphere 84 (8): 1140-1149.

Powers J. 1981. Confedrate niter production. NSS Bulletin 43: 94-97.

Reed T, McFarland T, Fryar AE, Fogle AW, Taraba JL. 2010. Sediment discharges during storm flow from proximal urban and rural karst springs, central Kentucky, USA. Journal of Hydrology 383 (3): 280-290.

Schwarzenbach RP, Gschwend PM, Imboden DM 2002. Environmental Organic Chemistry, 2nd Edition. New York: John Wiley.

Talarovich SG, Krothe NC. 1998. Three-component storm hydrograph separation of a karst spring contaminated by polychlorinated biphenyls in central Indiana. Environmental Geosciences 5 (4): $162-176$.

Vesper DJ. 2002. Transport and Storage of Trace Metals in a Karst Aquifer: An Example from
Fort Campbell, Kentucky. [Ph.D. Dissertation], Pennsylvania State University. 253 p.

Vesper DJ, White WB. 2003. Metal transport to karst springs during storm flow: An example from Fort Campbell, Kentucky/Tennessee, U.S.A. Journal of Hydrology 276: 20-36.

Vesper DJ, White WB. 2004. Spring and conduit sediments as storage reservoirs for heavy metals in karst aquifers. Environ Geol 45 (4): 481-493.

Yun Y, Wang H, Man B, Xiang X, Zhou J, Qiu X, Duan Y, Engel AS. 2016. The Relationship between $\mathrm{pH}$ and Bacterial Communities in a Single Karst Ecosystem and Its Implication for Soil Acidification. Frontiers in Microbiology 7: 1955. 